\title{
SIMULASI PERUBAHAN SOSIO-EKONOMI SERTA STRATEGI RUMAHTANGGA NELAYAN SKALA KECIL DALAM MEMPERTAHANKAN EKONOMI DAN KETAHANAN PANGAN RUMAHTANGGA DI PEDESAAN PANTAI JAWA TIMUR
}

\author{
Pudji Purwanti ${ }^{1}$ \\ 1Dosen Jurusan Sosial Ekonomi Fakultas Perikanan dan IImu Kelautan Universitas Brawijaya \\ Jl. Veteran Malang 65145 telp 0341-553512 \\ E-mail:pudjipur_fpi_ub@yahoo.com \\ Diterima 23 Maret $20 \overline{1} 0$ - Disetujui 26 Juni 2010
}

\begin{abstract}
ABSTRAK
Penelitian bertujuan untuk menganalisa dampak perubahan parameter ekonomi seperti kenaikan BBM, kenaikan harga kebutuhan pokok, dan strategi rumahtangga dalam meningkatkan pendapatan melalui penambahan curahan kerja non perikanan. Penelitian ini menggunakan model simulasi dengan metode Two Stage Least Squares (2SLS) untuk menganalisa perubahan ekonomi dan ketahanan pangan rumah tangga nelayan di Kabupaten Pasuruan dan Trenggalek, Provinsi Jawa Timur. Hasil simulasi menunjukkan bahwa kenaikan sebesar $30 \%$ untuk biaya operasional melaut dan harga bahan pokok pangan harus diimbangi dengan meningkatnya curahan kerja suami dan istri masing-masing $15 \%$. Kenaikan tersebut juga menyebabkan penurunan ketahanan pangan rumah tangga nelayan. Hasil penelitian menyimpulkan rumahtanga nelayan skala kecil dapat mempertahankan ketahanan pangannya dengan memanfaatkan waktu kerja di rumah dan senggang istri nelayan sebagai waktu produktif berorientasi pasar.
\end{abstract}

Kata kunci : ekonomi rumahtangga, ketahanan pangan, nelayan skala kecil

\section{Abstract: Simulation of Socio-economic and Strategies of Small-scale Fisher's Household for Rural Households Economic and Food Security in in East Java's Coasts. By: Pudji Purwanti}

This research aims to analyze impact of economics changes parameter, such as increasing of fuel price, primary consumption and households strategies to increase their incomes by adding non-fishing work outflow. It uses a simulation model approach with Two Stage Least Squares (2SLS) method to analyze economics changes and food security of fishers households in Pasuruan and Trenggalek districts, East Java Province. Simulation results show that $30 \%$ increase in fishers operational cost and primary consumption price should be fulfilled by $15 \%$ increasing of work outflow from husband and wife in household. This increasing also leads to declining of fisherman households' food security. This research conclude that smallscale fishers household can keep their households food security by utilizing of theirs wife leisure time productivelyoriented to market .

Keywords : household economic, food security, small-scale Fisherman 


\section{PENDAHULUAN}

Ketahanan pangan merupakan konsep yang kompleks yang terkait dengan mata rantai sistem pangan dan gizi mulai dari produksi, distribusi, konsumsi dan status gizi. Ketahanan pangan adalah kondisi dimana manusia memiliki akses yang penuh baik secara fisik dan ekonomi dapat mencukupi nutrisi makanan dan keamanan dalam menyediakan kebutuhan pangan dalam kehidupan yang sehat sesuai dengan nilai dan budaya setempat. Dalam sistem ketahanan pangan, kemampuan rumah tangga mengendalikan pasokan pangan untuk keluarganya (food entitlement) perlu menjadi perhatian.

Suatu rumah tangga dapat mencapai kondisi tahan pangan sangat berkaitan erat dengan perilaku ekonomi rumah tangga. Dalam hal ini pengambilan keputusan rumah tangga pada kegiatan produksi dan konsumsi, serta alokasi waktu kerja dan pendapatan rumah tangga. Salah satu strategi rumahtangga nelayan dalam rangka mencukupi kebutuhan pangan adalah keputusan dalam mengalokasikan waktu kerjanya untuk berproduksi baik kegiatan pada sektor perikanan maupun pekerjaan di luar sektor perikanan.

Menurut Direktorat Jenderal Perikanan (1993) sumber pendapatan nelayan dari kegiatan non perikanan seperti buruh tani, karyawan dan tukang berkisar antara 22,00 \% - 43,00 \%. Namun beberapa temuan dari hasil penelitian menunjukkan sumber pendapatan rumahtangga nelayan hanya dari sektor perikanan (Zulkifli, 1992; Muhammad dkk, 1991; Qoid dkk, 2004). Dari sisi curahan waktu nelayan, hampir seluruh waktu kerja nelayan dihabiskan untuk kegiatan melaut (Purwanti 1994; Purwono, 1991).

Perubahan kondisi perekonomian, serta kebijakan pemerintah pada saat ini sangat mempengaruhi perilaku ekonomi rumahtangga nelayan dan ketahanan pangan. Dalam kurun waktu dua tahun terakhir, harga bahan pokok terus mengalami kenaikan. Harga beras dan minyak goreng telah naik mencapai $100 \%$, harga gula dan terigu naik hampir $75 \%$, demikian juga bahan pokok lainnya seperti telur. Kondisi kenaikan harga bahan pokok pangan yang cenderung terus meningkat dalam beberapa tahun terakhir tentu sangat berimbas pada ekonomi rumah tangga nelayan.

Harga minyak dunia dalam perdagangan internasional juga mengalami fluktuasi. Adanya kenaikan bahan bakar BBM pada pasar dunia tentu akan direspon dengan kebijaksanaan pemerintah untuk menaikkan harga BBM dalam negeri, seperti yang terjadi pada tahun 2008. Pada tingkat rumahtangga nelayan, BBM merupakan kebutuhan utama dalam kegiatan penangkapan ikan di laut, karena BBM merupakan komponen biaya produksi yang dominan sebagai bahan bakar penggerak mesin perahu.

Tujuan dari penelitian ini adalah: (1) melakukan simulasi peningkatan harga BBM dan peningkatan harga bahan pokok pangan terhadap ekonomi rumahtangga dan ketahanan pangan nelayan skala kecil (2) melakukan simulasi strategi rumahtangga dalam meningkatkan pendapatan melalui penambahan curahan kerja non perikanan akibat adanya kenaikan harga BBM dan kenaikan harga bahan pokok pangan. Hasil dari penelitian ini diharapkan dapat digunakan sebagai bahan pertimbangan pemerintah dalam pengambilan kebijaksanaan kenaikan harga BBM dan stabilitas harga bahan pokok, serta pembinaan ekonomi rumahtangga nelayan.

\section{METODOLOGI}

Penelitian ini dilakukan di wilayah Jawa Timur. Pemilihan lokasi berdasarkan tipe sumberdaya Laut Utara dan Laut Selatan. Adanya sarana pelabuhan perikanan yang menunjukkan aktivitas perekonomian masyarakat pantai serta memperoleh program pemberdayaan Dinas Kelautan dan Perikanan 
Propinsi Jawa Timur. Berdasarkan pertimbangan faktor di atas, maka lokasi penelitian yang mewakili wilayah Laut Selatan terpilih Desa Tasikmadu Kecamatan Watulimo Kabupaten Trenggalek, sedangkan lokasi wilayah Laut Utara terpilih Desa Jatirejo Kecamatan Lekok Kabupaten Pasuruan. Penelitian dilaksanakan pada pertengahan bulan Juli hingga Agustus 2008.

Penelitian ini dilakukan dengan metode survei yaitu menggambarkan secara sistematik dan faktual mengenai fenomena yang ada sekarang. Jumlah sampel dari masing-masing desa terpilih di kabupaten terpilih diambil sejumlah 40 unit usaha penangkapan ikan skala kecil secara acak sederhana (random sampling). Total contoh untuk 2 wilayah kabupaten terpilih adalah 80 (delapanpuluh) rumahtangga nelayan skala kecil, yang memiliki faktor produksi dengan jenis alat tangkap yang berbeda. Pengambilan sampel sejumlah 80 responden dengan asumsi bahwa populasi mempunyai distribusi normal, batasan minimum sampel sebanyak 30 unit (Walpole, 1995). Jenis data rumahtangga yang dikumpulkan meliputi data karakteristik rumahtangga dan usaha penangkapan ikan secara umum, penggunaan input, produksi ikan, curahan kerja rumahtangga, biaya, sumber dan besarnya pendapatan, serta pengeluaran untuk konsumsi pangan dan non pangan.

Data dianalisis berdasarkan model ekonometrika persamaan simultan melalui pendekatan ekonomi rumahtangga nelayan dengan membagi kegiatan ekonomi rumahtangga menjadi 4 blok kegiatan ekonomi antara lain produksi, curahan kerja, pendapatan rumahtangga dan konsumsi. Perilaku ekonomi rumahtangga tersebut mengacu pada model dasar analisis rumah tangga pertanian (Agriculture Household Model) yang disusun Singh et al. (1986) sebagai model dasar ekonomi rumahtangga. Model tersebut telah dikembangkan oleh beberapa peneliti di perdesaan pantai antara lain; Aryani (1994), Reniati (1998) Muhammad
(2002), Sutoyo (2005) dan Tumulyadi (2005). Masing-masing blok dianalisis menggunakan metode analisis regresi berganda yang diestimasi secara simultan dengan mengaitkan Indeks ketahanan pangan rumah tangga nelayan yang diukur melalui Indeks Kecukupan Energi, Indeks Kecukupan Protein dan Porsi Pengeluaran Pangan. Berdasarkan data yang telah diperoleh, kemudian dilakukan pendugaan model dengan metode Two Stage Least Squares (2SLS). Pengolahan data dilakukan dengan program SAS (Statistical System). Persamaan pendugaan model rumahtangga sebagai berikut:

$$
\begin{aligned}
& \text { Produksi melaut (fishing production) : } \\
& \begin{aligned}
\text { QMP }= & a_{0}+a_{1} \text { UPJCB }+a_{2} J B B M P+a_{3} T H O K P+ \\
& a_{4} S R T+a_{5} D 1+\mu_{1} \\
\text { QMS }= & b_{0}+b_{1} J B B M S+b_{2} \text { THOKS }+b_{3} S R T+b_{4} \\
& D 2+b_{5} D 1+\mu_{2}
\end{aligned}
\end{aligned}
$$

\section{Total produksi melaut:}

QMPMS = QMP + QMS

QMP = Produksi penangkapan musim puncak (kg)/fishing production in peak season

QMS = Produksi penangkapan musim s e d a ng ( $\mathrm{kg}) / f i$ s $h$ ing production in medium season

UPJCB = Ukuran perahu dan jumlah cold box /boat size variable and the numbers of cool box

JBBMP = Jumlah bahan bakar musim puncak (It) /the number of motor fuel in peak season

JBBMS = Jumlah bahan bakar musim sedang (It) /the number of motor fuel in medium season

THOKP = Curahan tenaga kerja musim puncak (HOK)/fishing allocation time in peak season

THOKS = Curahan tenaga kerja musim sedang (HOK)/fishing allocation time in medium season

SRT = Surplus Rumah Tangga $(R p) /$ household surplus

D1 = Status sumberdaya di wilayah penangkapan ikan / 
catching resource status

D2 = Status nelayan penerima kredit atau tidak/fisherman status whether credit receiver or not

QMPMS = Total produksi melaut / Total fishing production behavior

Curahan kerja melaut (fishing time allocation):

THOKP $=\mathrm{c}_{0}+\mathrm{c}_{1} \mathrm{KFMP}+\mathrm{C}_{2} \mathrm{D} 1+\mu_{3}$

THOKS $=d_{0}+d_{1}$ ASET $+d_{2}$ IRT $+d_{3}$ D1 $1+\mu_{4}$

Total curahan kerja melaut (THOK):

THOK = THOKP + THOKS

THOKP = Curahan tenaga kerja melaut musim puncak (HOK) /fishing allocation time in peak season

THOKS = Curahan tenaga kerja melaut musim sedang ( $\mathrm{HOK}$ ) /fishing allocation time in medium season)

KFMP = Keuntungan penangkapan musim puncak (Rp)/fishing income in eak season

ASET = Nilai Asset kapal dan alat tangkap (Rp)/number of asset used by fishing activities

IRT = Total pendapatan rumahtangga nelayan (Rp/thn)/household fisheries'total income)

Penerimaan melaut (persamaan identitas) :

RMP = QMP * HIMP

RMS $\quad=$ QMS * HIMS

RF $\quad=$ RMP + RMS

RMP = Penerimaan melaut puncak /

Peak season revenue

RMS = Penerimaan melaut sedang /

Medium season revenue

Biaya operasi melaut (fishing operational cost):

TBOMP $=\mathrm{e}_{0}+\mathrm{e}_{1}$ THOKP $+\mathrm{e}_{2}$ ASET $+\mu_{5}$

TBOMS $=\mathrm{f}_{0}+\mathrm{f}_{1} \mathrm{THOKS}+\mathrm{f}_{2} \mathrm{ET}+\mu_{6}$

Total biaya operasi melaut (BOF):

BOF = TBOMP + TBOMS

TBOMP = Biaya operasi melaut musim puncak (Rp)/fishing operational cost in peak season

TBOMS = Biaya operasi melaut musim sedang $(\mathrm{Rp}) /$ fishing operational cost in medium season

\begin{tabular}{|c|c|c|}
\hline \\
\hline \multicolumn{3}{|c|}{$\begin{array}{l}\text { Keuntungan melaut: } \\
\text { KFMP = RMP-TBOMP }\end{array}$} \\
\hline \multirow{3}{*}{$\begin{array}{l}\text { KFMS } \\
\text { TKF } \\
\text { KFMP }\end{array}$} & $=\mathrm{RMS}-\mathrm{TBOMS}$ & \\
\hline & $=\mathrm{KFMP}+\mathrm{KFMS}$ & \\
\hline & =Keuntungan melaut & musim \\
\hline & $\begin{array}{l}\text { puncak/ fishing profit } \\
\text { season }\end{array}$ & in peak \\
\hline KFMS & =Keuntungan melaut & musim \\
\hline & $\begin{array}{l}\text { sedang/fishing profit in } \\
\text { season }\end{array}$ & medium \\
\hline \multirow[t]{2}{*}{ TKF } & $=$ Total keu & ut /Total \\
\hline & fishing pro & \\
\hline
\end{tabular}

\section{Pendapatan Rumah Tangga lainnya:}

RRTL = RABK + RNF + ROF

\section{*) Pendapatan non perikanan}

$\mathrm{RNF} \quad=\mathrm{g}_{0}+\mathrm{g}_{1} \mathrm{KNFI}+\mathrm{g}_{2} \mathrm{KNFS}+\mathrm{g}_{3}$ PDDI+ $\mathrm{g}_{4} \mathrm{THOK}{ }_{7}$

Total Pendapatan Rumah Tangga nelayan:

IRT = TKF + RRTL

RRTL = Pendapatan rumahtangga lainnya lother household revenue

RNF = Pendapatan non perikanan Inon fishing revenue

IRT = Total pendapatan rumahtangga /Total household income

$\mathrm{KNFI}=$ Curahan kerja istri (HOK) /wives' productivity time allocation

KNFS = Curahan kerja Non Fishing suami (HOK) /husbands' non-fishing time allocation

PDDI = Tingkat pendidikan istri (thn) /wives educational level

THOK = Total hari kerja suami pada kegiatan melaut (HOK /total fishing time allocated days)

Pengeluaran rumahtangga (PRT):

PRT = PPGN + PNPGN

*) Pengeluaran pokok pangan

PPGN $=h_{0}+h_{1} I R T+h_{2} J A K+h_{3} D_{2}+{ }_{8}$ 
*) Pengeluaran Non Pokok Pangan

PNPGN $=i_{0}+i_{1} J A K+i_{2}$ QMPMS $+i_{3} R R T L+{ }_{9}$

*) Pengeluaran beras (CBR) :

$\mathrm{CBR}=\mathrm{j}_{0}+\mathrm{j}_{1} \mathrm{IRT}+\mathrm{j}_{2} \mathrm{JAK}+{ }_{10}$

*) Pengeluaran Ikan (Cl) :

$\mathrm{Cl}=\mathrm{k}_{0}+\mathrm{k}_{1}$ IRT $+\mathrm{k}_{2}$ PDDI $+\mathrm{k}_{3}$ QMPMS $++_{11}$

*) Pengeluaran sayuran (CSy):

CSy $=\mathrm{I}_{0}+\mathrm{I}_{1}$ IRT $+\mathrm{I}_{2} \mathrm{Cl}+{ }_{12}$

PRT = Total pengeluaran rumahtangga /Total household expenditures)

PPGN =Pengeluaran pokok pangan/ the major food expenditures

PNPGN= Pengeluaran non pokok pangan/ the major non food expenditure

JAK = Jumlah anggota keluarga/ the number of family members

$\mathrm{CBR}=$ pengeluaran beras $/$ rice consumption

$\mathrm{Cl}=$ pengeluaran ikan/ fish consumption

CSy = pengeluaran sayuran/ vegetables consumption

Surplus Rumah Tangga (SRT):

SRT = IRT - PRT

\section{HASIL DAN PEMBAHASAN}

\section{Hasil Estimasi Model Ekonomi Rumah tangga Nelayan}

Model persamaan simultan yang dihasilkan dalam penelitian ini terdiri dari 31 peubah endogen, yang disusun dalam bentuk persamaan ekonometrik sebanyak 31 persamaan terdiri dari 12 persamaan struktural dan 19 persamaan identitas. Estimasi terhadap parameter-parameter pada persamaan simultan dilakukan dengan menggunakan metode 2 SLS (Two Stage Least Squares). Hasil estimasi dari model disajikan pada lampiran 1. Sedangkan persamaan perilaku ekonomi rumahtangga nelayan skala kecil disajikan pada tabel 2 .

Perilaku berproduksi pada usaha penangkapan ikan pada umumnya dilakukan pada saat musim puncak dan musim sedang. Berdasarkan pengujian kriteria $F$ value produksi melaut musim puncak dipengaruhi secara bersama-sama oleh variabel ukuran

Tabel 2. Persamaan Model Perilaku Ekonomi Rumah Tangga Skala Kecil

Table 2. Model Equition of the Behavior of Small-scale Fisher's Household Economy

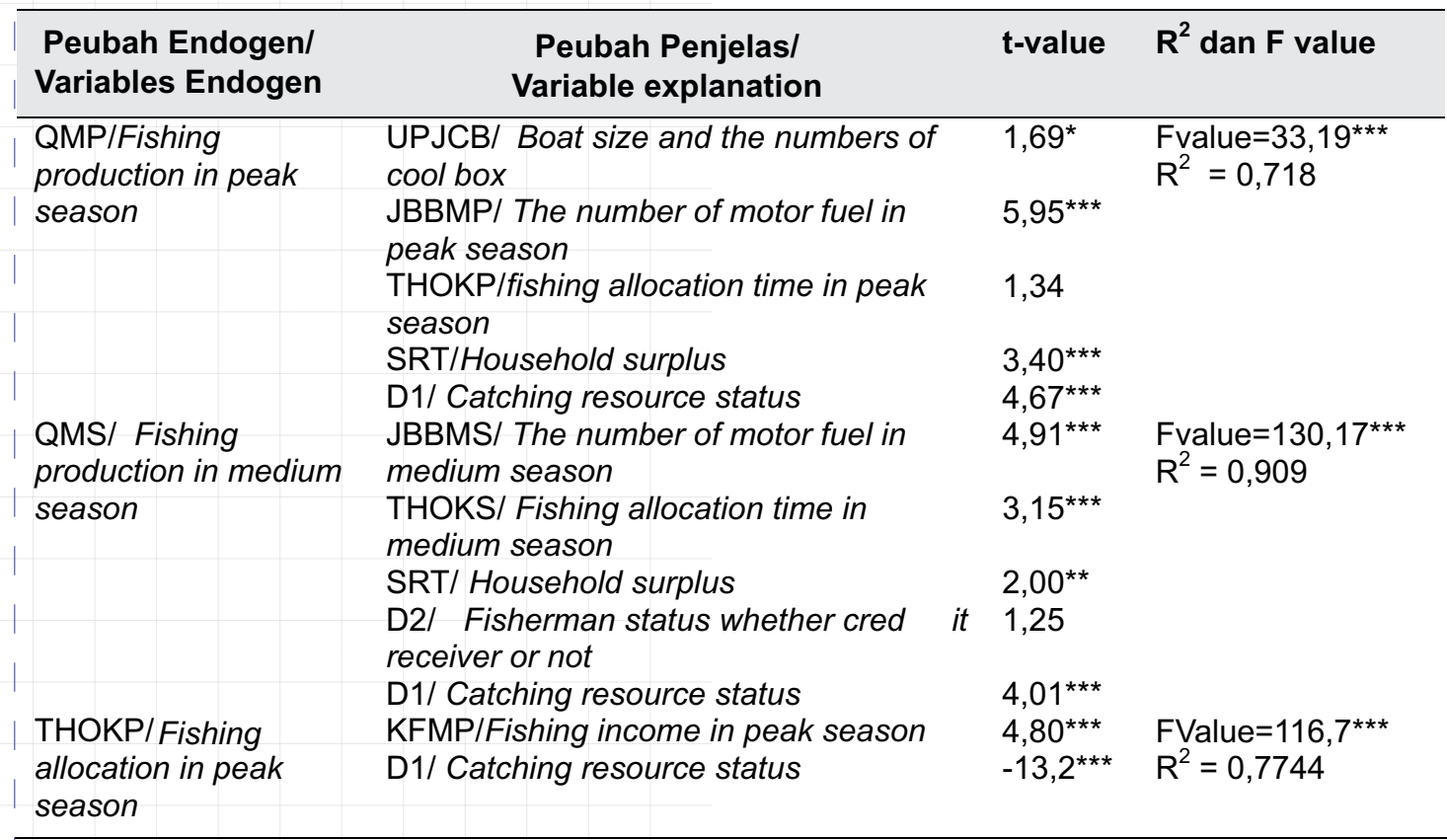


Lanjutan Tabel 2/ Continued Table 2

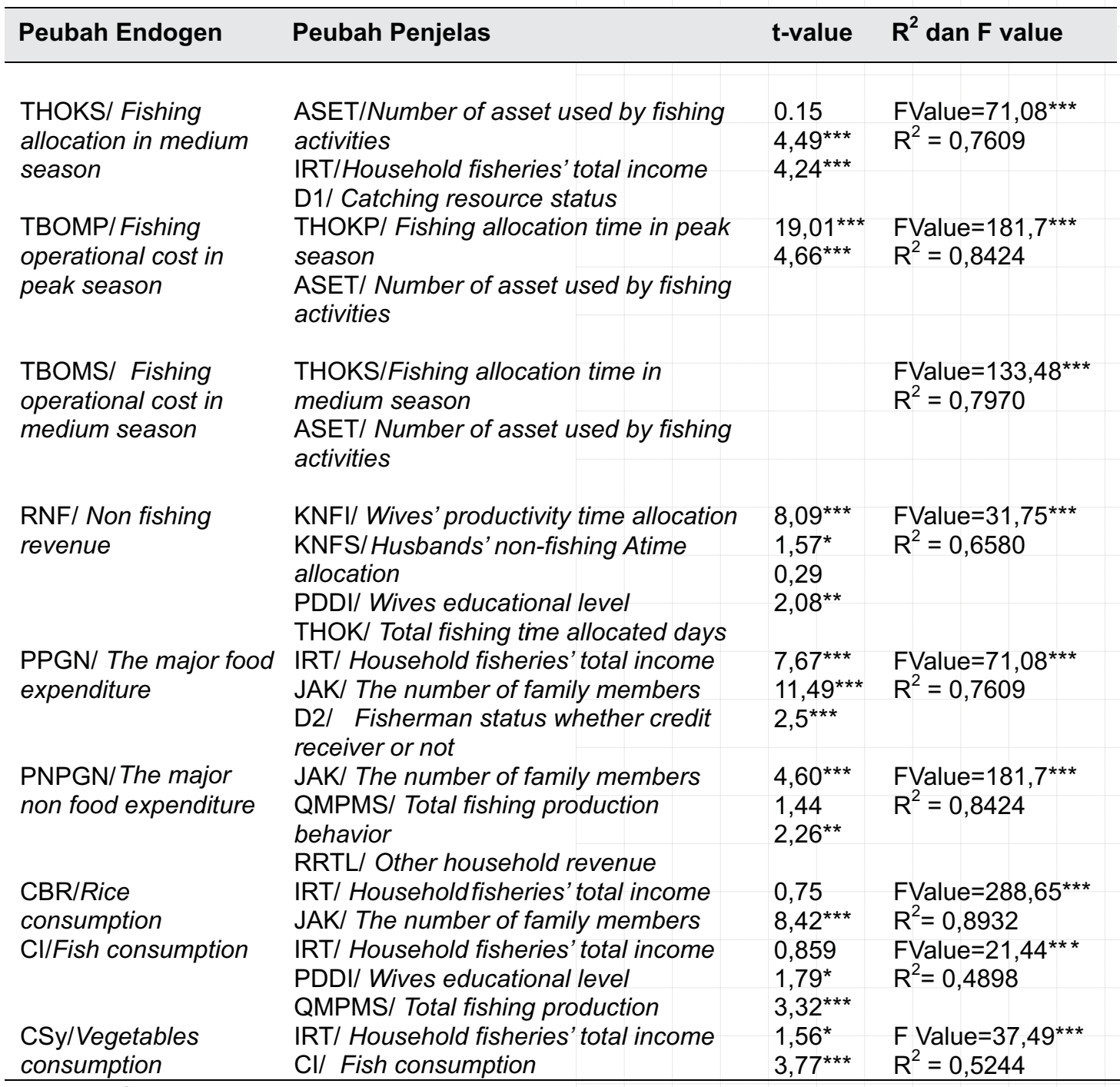

Keterangan/Remaxs

*** nyata pada taraf kesalahan $1 \%$

** nyata pada taraf kesalahan $5 \%$

* nyata pada taraf kesalahan $10 \%$

perahu dan jumlah cold box (UPJCB), jumlah bahan bakar motor (JBBMP), curahan kerja melaut musim puncak (THOKP), surplus rumahtangga nelayan (SRT) dan status sumberdaya penangkapan (D1). Secara parsial, ukuran perahu dan jumlah cold box (UPJCB) yang lebih besar memudahkan nelayan dalam mengangkut hasil tangkapan pada musim puncak.
Peningkatan penggunaan BBM akan meningkatkan hasil tangkapan ikan.

Penggunaan BBM yang meningkat akan menyebabkan jangkauan daerah penangkapan Ikan yang semakin luas dan meningkatkan produksi. Dalam hal curahan waktu kerja, nelayan cukup memanfaatkan curahan kerjanya pada musim puncak guna 
memperoleh hasil tangkapan yang banyak. Surplus rumah tangga nelayan kecil berpengaruh positif nyata terhadap hasil produksi ikan pada musim puncak. Kelebihan pendapatan rumahtangga setelah dikeluarkan untuk konsumsi dimanfaatkan untuk kegiatan produksi melaut. Status wilayah sumberdaya berpengaruh positif nyata. Ini berarti wilayah Kecamatan Prigi Kabupaten Trenggalek yang berada di wilayah laut selatan Jawa memiliki hasil produksi yang lebih tinggi dibandingkan dengan wilayah Kecamatan Lekok Kabupaten Pasuruan yang berada di wilayah laut utara jawa.

Perilaku produksi musim sedang dipengaruhi secara bersama-sama oleh variabel jumlah bahan bakar motor, curahan kerja melaut musim sedang, status nelayan penerima kredit atau tidak dan status sumberdaya wilayah penangkapan. Jumlah BBM yang digunakan dalam musim sedang berpengaruh positif nyata terhadap hasil produksi penangkapan ikan. Dalam hal curahan waktu kerja musim sedang, nelayan memanfaatkan curahan kerjanya untuk bekerja dengan giat, karena produksi ikan tidak sebanyak pada musim puncak. Surplus rumahtangga nelayan kecil berpengaruh positif nyata terhadap hasil produksi ikan pada musim sedang. Status nelayan penerima kredit atau tidak, berpengaruh positif kurang nyata terhadap hasil produksi pada musim sedang. Hal ini berarti kredit yang diterima nelayan penerima kredit tidak secara langsung digunakan untuk meningkatkan produksi, namun lebih mengarah pada interaksi sosial dalam bentuk "patron-client" antara nelayan dengan pelepas uang.

Perilaku curahan kerja melaut musim puncak dipengaruhi secara bersama-sama oleh variabel pendapatan melaut pada musim puncak dan status sumberdaya penangkapan. Pendapatan melaut pada musim puncak berpengaruh positif nyata terhadap curahan kerja melaut musim puncak. Kenaikan pendapatan melaut akan menyebabkan individu menambah jam kerjanya. Dengan demikian sesuai dengan kurva penawaran tenaga kerja individu, pada musim puncak kondisi kurva naik.

Status wilayah sumberdaya berpengaruh negatif nyata yang berarti wilayah Kecamatan Prigi Kabupaten Trenggalek memiliki curahan kerja pada musim puncak yang lebih rendah dibandingkan dengan wilayah Kecamatan Lekok Kabupaten Pasuruan. Pada musim puncak nelayan Prigi cenderung lebih rendah mencurahkan waktu kerjanya pada kegiatan penangkapan ikan di laut. Hal ini karena sumberdaya laut di Prigi masih dalam keadaan "under exploited" sehingga pada musim puncak nelayan Prigi relatif membutuhkan waktu yang lebih pendek untuk mencukupi hasil tangkapan ikan sesuai dengan kapasitas perahunya.

Perilaku curahan kerja melaut musim sedang dipengaruhi secara bersama-sama oleh variabel besarnya aset yang digunakan nelayan dalam kegiatan melaut, total pendapatan rumahtangga nelayan dan status sumberdaya penangkapan. Nilai aset kapal, alat tangkap dan mesin tidak berpengaruh nyata terhadap curahan kerja melaut pada musim sedang.

Total pendapatan rumah tangga nelayan berpengaruh positif nyata terhadap curahan kerja melaut pada musim sedang. Total pendapatan rumah tangga terdiri dari pendapatan melaut, pendapatan off fishing dan pendapatan non fishing. Dengan meningkatnya total pendapatan rumahtangga maka nelayan skala kecil akan meningkatkan curahan waktu kerja di laut pada musim sedang. Pada musim sedang, nelayan skala kecil di wilayah Kecamatan Prigi Kabupaten Trenggalek memiliki curahan waktu kerja yang lebih tinggi dibandingkan dengan wilayah Kecamatan Lekok Kabupaten Pasuruan. Hal ini disebabkan karena kondisi perairan di wilayah Kecamatan Lekok Kabupaten Pasuruan yang telah "over fishing". Sedangkan pada wilayah Kecamatan Prigi Kabupaten Trenggalek masih dalam kondisi "under fishing" sehingga pada saat musim 
sedang nelayan Prigi membutuhkan curahan waktu kerja yang lebih banyak dibandingkan dengan pada saat musim puncak, hingga melebihi curahan kerja nelayan Lekok.

Model persamaan biaya operasi melaut dapat dibedakan menjadi dua yaitu model biaya operasi musim puncak dan model biaya operasi musim sedang. Biaya operasi melaut baik musim puncak maupun musim sedang dipengaruhi secara bersama-sama oleh variabel curahan kerja melaut pada musim puncak atau sedang dan besarnya nilai aset yang digunakan nelayan kecil. Total curahan kerja melaut musim puncak berpengaruh positif nyata terhadap biaya operasi melaut musim puncak. Total curahan kerja melaut musim sedang dipengaruhi biaya operasi melaut musim sedang. Komponen utama biaya operasi melaut terdiri dari biaya BBM, dan biaya perbekalan. Nilai aset yang dibutuhkan dalam kegiatan penangkapan ikan di laut berpengaruh positif nyata pada total biaya operasional melaut pada musim puncak maupun musim sedang. Nilai aset ini terdiri dari harga kapal, harga alat tangkap dan harga mesin penggerak perahu. Semakin besar nilai asetnya maka ukuran kapal dan mesin penggeraknya semakin lebih besar,sehingga untuk menggerakkan kapal tersebut diperlukan biaya bahan bakar yang lebih banyak. Hal ini sama juga berlaku untuk biaya perbekalan. Dengan demikian semakin besar nilai aset yang digunakan akan meningkatkan biaya operasi melaut.

Perilaku pendapatan non perikanan rumahtangga nelayan dipengaruhi secara bersama-sama oleh variabel curahan kerja non fishing istri, curahan kerja non fishing suami, tingkat pendidikan istri dan total hari kerja melaut. Curahan kerja istri yang semakin tinggi akan meningkatkan pendapatan non perikanan dalam rumahtangga nelayan. Hal ini menunjukkan bahwa peran istri dalam kegiatan produksi pasar memberikan kontribusi yang sangat nyata terhadap pendapatan rumahtangga. Semakin tinggi curahan kerja suami pada kegiatan non fishing akan meningkatkan pendapatan non perikanan rumahtangga nelayan. Pendidikan istri berpengaruh positif kurang nyata terhadap pendapatan non fishing. Hal ini disebabkan karena jenis pekerjaan istri pada umumnya hanya membutuhkan kemauan untuk bekerja dan ketrampilan dalam usahanya. Semakin tinggi total hari orang kerja perikanan dalam rumahtangga nelayan menyebabkan pendapatan non fishing rumah tangga nelayan meningkat. Ini berarti bahwa rumahtangga nelayan sangat giat dalam kegiatan berproduksi baik produksi fishing maupun non fishing. Pendapatan rumahtangga yang tinggi merupakan cara rumahtangga nelayan untuk mencapai ketahanan pangan.

Pengeluaran pokok pangan rumahtangga nelayan dipengaruhi secara bersama-sama oleh total pendapatan rumahtangga, jumlah anggota keluarga, dan status nelayan penerima kredit. Semakin tinggi pendapatan rumahtangga maka semakin meningkat pula pengeluaran pokok pangan dalam rumahtangga nelayan. Ini berarti apabila pendapatan rumahtangga meningkat, maka rumahtangga ingin meningkatkan kualitas pangan. Dengan demikian anggaran untuk pengeluaran pokok pangan lebih meningkat.

Semakin banyak anggota keluarga, maka akan semakin meningkatkan pengeluaran pokok pangan dalam rumahtangga nelayan. Status nelayan penerima kredit mempengaruhi pula pengeluaran pokok rumahtangga nelayan. Kredit yang diberikan nelayan dari para bakul ikan sebagai ikatan dalam penjualan hasil tangkapan lebih digunakan untuk pengeluaran pokok pangan, dan hanya sebagian kecil digunakan untuk kegiatan produksi.

Kebutuhan konsumsi pangan rumahtangga yang mendasar guna terpenuhi pola hidup sehat harus memenuhi 4 sehat 5 sempurna yaitu karbohidrat, protein, sayuran, buah-buahan dan susu. Perilaku konsumsi pangan rumahtangga nelayan berikut dilihat 
berdasarkan pemenuhan kebutuhan beras sebagai sumber karbohidrat, ikan sebagai pemenuhan protein serta sayuran. Ikan merupakan hasil tangkapan nelayan, selain dijual untuk dipertukarkan dengan beras dan kebutuhan lain, juga dikonsumsi sendiri guna mencukupi kebutuhan protein.

Konsumsi beras secara bersama-sama dipengaruhi oleh variabel total pendapatan rumahtangga nelayan dan jumlah anggota keluarga. Secara parsial kenaikan total pendapatan rumahtangga nelayan secara langsung tidak meningkatkan konsumsi beras. Konsumsi beras dalam rumahtangga responden telah tercukupi, dengan nilai ratarata 260 gram/orang/hari. Semakin banyak jumlah anggota keluarga maka semakin bertambah kebutuhan beras untuk memenuhi konsumsi beras dalam rumahtangga nelayan.

Konsumsi ikan dalam rumahtangga nelayan kecil secara bersama-sama dipengaruhi oleh total pendapatan dalam rumahtangga, tingkat pendidikan ibu dan total produksi melaut. Secara parsial kenaikan total pendapatan rumahtangga nelayan secara langsung kurang meningkatkan konsumsi ikan, karena rumahtangga nelayan mencukupi kebutuhan konsumsi ikan berasal dari hasil tangkapan, bukan dari membeli.

Tingkat pendidikan istri berpengaruh positif nyata terhadap konsumsi ikan dalam rumahtangga nelayan. Semakin tinggi tingkat pendidikan ibu, maka semakin meningkat konsumsi ikan dalam rumah tangga nelayan. Semakin banyak produksi hasil tangkapan, maka semakin meningkat pula bagian dari produksi tersebut untuk dikonsumsi sendiri. Tidak semua produksi hasil tangkapan ikan dijual, namun beberapa bagian dari hasil tangkapan dikonsumsi sendiri sebagai "lawuhan" (lauk pauk).

Konsumsi sayur dipengaruhi secara bersama-sama oleh variabel total pendapatan dalam rumahtangga nelayan dan konsumsi ikan melalui pengujian kriteria $F$ Value. Kenaikan total pendapatan rumahtangga nelayan secara langsung kurang meningkatkan konsumsi sayur, karena sebagian besar responden dari wilayah Prigi mencukupi kebutuhan konsumsi sayur berasal dari hasil tanaman sendiri, bukan dari membeli. Semakin banyak konsumsi ikan dalam rumahtangga nelayan, maka semakin meningkat kebutuhan rumahtangga terhadap konsumsi sayur. Ini berarti antara ikan dan sayur merupakan kebutuhan konsumsi yang saling melengkapi (komplementer).

\section{Validasi Model}

Validasi model dimaksudkan untuk mengetahui daya prediksi peubah endogen dalam model ekonomi rumahtangga dan ketahanan pangan rumahtangga nelayan. Hasil dari validasi model dapat menggambarkan informasi yang tidak jauh berbeda dengan nilai aktualnya. Pindyck dan Rubinfeld (1991) menunjukkan bahwa banyak kriteria yang dapat digunakan untuk mengevaluasi kinerja dari model simulasi yang kadang-kadang hasilnya tidak konsisten. Dalam hal ini diperlukan kompromi antara kepentingan statistik dengan kelengkapan model ekonomi yang dibangun. Pada Tabel 3. disajikan hasil uji statistik untuk memprediksi model.

Hasil uji statistik tingkat daya prediksi model yang disajikan dalam Tabel 3 . menunjukkan bahwa peubah endogen dalam model ekonomi rumahtangga nelayan kecil diperoleh rata-rata prediksi relatif mendekati rata-rata aktual sehingga model tersebut mempunyai hasil yang cukup baik. Nilai UM mendekati nol, artinya model tidak mengalami bias yang sistematik. Demikian juga nilai US mendekati nol yang berarti hasil analisis simulasi dapat mengikuti dengan baik fluktuasi data aktualnya. Sedangkan nilai UC mendekati nilai satu, artinya kesalahan tidak berarti dan tidak mengikuti pola tertentu, tetapi menyebar pada semua contoh pengamatan. Berdasarkan hasil analisis validasi model tersebut, maka model ekonomi dan ketahanan pangan rumahtangga nelayan kecil cukup valid untuk dipergunakan sebagai alat simulasi. 
Tabel 3. Hasil Uji Statistik Daya Prediksi Model

Table 3. Statistical Test Result of the Predicted Model

\begin{tabular}{|c|c|c|c|c|c|}
\hline $\begin{array}{l}\text { Peubah/ } \\
\text { Variables }\end{array}$ & $\begin{array}{c}\text { Rata-rata } \\
\text { Aktual/ } \\
\text { Actual } \\
\text { Average }\end{array}$ & $\begin{array}{c}\text { Rata-rata } \\
\text { Prediksi/ } \\
\text { Average } \\
\text { Prediction }\end{array}$ & $\begin{array}{l}\text { Proporsi } \\
\text { bias/ } \\
\text { Proportion } \\
\text { refraction } \\
\text { (UM) }\end{array}$ & $\begin{array}{l}\text { Proporsi } \\
\text { varian I } \\
\text { Proportion } \\
\text { variants } \\
\text { (US) }\end{array}$ & $\begin{array}{l}\text { Proporsi } \\
\text { co varian/ } \\
\text { Proportion } \\
\text { co variant } \\
\text { (UC) }\end{array}$ \\
\hline QMP/ Fishing production in peak & 3658 & 3446 & 0.016 & 0.122 & 0.730 \\
\hline $\begin{array}{l}\text { season } \\
\text { QMS/ Fishing production in medium }\end{array}$ & 2568 & 2440 & 0.009 & 0.068 & 0.923 \\
\hline $\begin{array}{l}\text { season } \\
\text { THOKP/ Fishing allocation in peak }\end{array}$ & 136.2254 & 132.9034 & 0.002 & 0.055 & 0.943 \\
\hline $\begin{array}{l}\text { season } \\
\text { THOKS/ Fishing allocation in }\end{array}$ & 124.9743 & 143.1084 & 0.004 & 0.036 & 0.960 \\
\hline medium season & & & & & \\
\hline THOK/Total fishing time allocation & 282.0687 & 276.0118 & 0.005 & 0.086 & 0.837 \\
\hline RMP/Peak season revenue & 14631380 & 13784722 & 0.016 & 0.122 & 0.730 \\
\hline RMS/Medium season revenue & 12369535 & 11389504 & 0.023 & 0.098 & 0.879 \\
\hline RF/ Total Fishing revenue & 27000915 & 25174226 & 0.025 & 0.054 & 0.921 \\
\hline $\begin{array}{l}\text { TBOMPI Fishing operational cost } \\
\text { in peak season }\end{array}$ & 5052536 & 3473562 & 0.262 & 0.139 & 0.599 \\
\hline $\begin{array}{l}\text { TBOMS/ Fishing operational cost in } \\
\text { medium season }\end{array}$ & 6564765 & 5166678 & 0.266 & 0.108 & 0.626 \\
\hline BOF/Total fishing operational cost & 11617301 & 8640240 & 0.528 & 0.006 & 0.466 \\
\hline KFMP/ Fishingprofit in peak season & 9578845 & 10311160 & 0.016 & 52 & 0.830 \\
\hline KFMS/Fishing profit in medium & 5804770 & 6222826 & 0.008 & 0.078 & 0.915 \\
\hline $\begin{array}{l}\text { season } \\
\text { TKF/Total fishing profit }\end{array}$ & 15383615 & 16533986 & 0.014 & 12 & 74 \\
\hline RRTL/Other Household revenue & 2394873 & 2343194 & 0.001 & 0.016 & 0.983 \\
\hline RNF/ Non fishing revenue & 1251831 & 1200152 & 0.001 & 0.017 & 0.982 \\
\hline IRT/Total Household Income & 17778488 & 18877180 & 0.011 & 0.088 & 0.968 \\
\hline PRT/Total Hous & 7552705 & 7538209 & 0.000 & 25 & 0.978 \\
\hline PPGN/ The major food expenditure & 5301874 & 5329999 & 0.001 & 0.001 & 0.982 \\
\hline $\begin{array}{l}\text { PNPGN/ The major non food } \\
\text { expenditure }\end{array}$ & 2250831 & 2208209 & 0.002 & 0.054 & 0.945 \\
\hline CBR/rice consumption & 281.8028 & 263.4303 & 0.038 & 0.049 & 0.913 \\
\hline $\mathrm{Cl} /$ Fish consumption & 112.1408 & 106.0260 & 0.017 & 0.012 & 0.971 \\
\hline CSy/Vegetables consumption & 122.9296 & 115.2276 & 0.005 & 0.056 & 0.939 \\
\hline SRT/Household Surplus & 10225783 & 11338972 & 0.016 & 16 & 0.919 \\
\hline AKE/Energy Sufficiency Value & 1716 & 1637 & 0.039 & 0.027 & 0.912 \\
\hline AKP/Protein Sufficiency Value & 56.4765 & 53.4805 & 0.025 & 0.029 & 0.883 \\
\hline PORPGN/ Food Expenditure & 36.3972 & 35.3951 & 0.003 & 0.063 & 0.975 \\
\hline Portion & & & & & \\
\hline Indeks AKE/AKE Index & 0.8578 & 0.8185 & 0.039 & 0.027 & 0.912 \\
\hline Indeks AKP/ AKE Index & 1.0861 & 1.0285 & 0.025 & 0.029 & 0.883 \\
\hline Indeks PORPGN/ Food & 2.3137 & 2.3636 & 0.004 & 0.027 & 0.981 \\
\hline Expenditure Portion Index & & & & & \\
\hline $\begin{array}{l}\text { Indeks Ketahanan Pangan/ Food } \\
\text { Secure Index }\end{array}$ & 1.4192 & 1.4035 & 0.002 & 0.000 & 0.992 \\
\hline
\end{tabular}




\section{Simulasi Dampak Perubahan Sosial Ekonomi Terhadap Ekonomi Rumah Tangga Nelayan}

Bahan bakar minyak (BBM) merupakan salah satu input yang paling utama dalam kegiatan penangkapan ikan. Dalam menghadapi harga minyak dunia yang makin meningkat, pemerintah menghindari instrumen subsidi dalam penjualan minyak dengan meminta masyarakat menghemat energi dalam penggunaan minyak. Akibat dari kenaikan harga minyak maka secara langsung akan berpengaruh terhadap kegiatan melaut melalui peningkatan biaya operasional melaut, mengingat BBM merupakan komponen biaya operasional yang paling dominan. Di sisi lain, beberapa tahun terakhir harga bahan pokok terus mengalami kenaikan. Dalam kurun waktu tahun 2007 hingga tahun 2009, harga beras dan minyak goreng telah naik mencapai $100 \%$, harga gula dan terigu naik hampir $75 \%$, demikian juga bahan pokok lainnya seperti telur dan gula.

Adanya kenaikan bahan bakar minyak bersama-sama dengan kenaikan harga bahan pokok tentu akan berpengaruh terhadap ekonomi rumahtangga nelayan skala secil. Oleh karena itu disimulasikan kenaikan biaya operasional penangkapan ikan 30\% akibat kenaikan BBM dan kenaikan harga bahan pokok sebesar 30\%. Hasil dari simulasi tersebut adalah penerimaan penangkapan ikan menurun $(-51,89 \%)$ total pendapatan rumahtangga menurun $(-47,71 \%)$, total pengeluaran rumahtangga meningkat $11,94 \%$ serta surplus rumahtangga turun $(-87,36 \%)$. Tingkat ketahanan pangan rumahtangga nelayan juga mengalami penurunan. Nilai Indeks AKE (-6,78\%), Indeks AKP (-18,25\%), Indeks Porsi Pengeluaran Pangan (-55,17\%) dan Indeks ketahanan pangan turun $-36,74 \%$. Kondisi rumahtangga nelayan menjadi kurang tahan pangan dengan nilai Indeks Ketahanan Pangan 0,887 .

\section{Strategi Rumahtangga dalam Mempertahankan Ekonomi dan Ketahanan Pangan Rumahtangga Nelayan Skala Kecil}

Salah satu strategi rumahtangga dalam menghadapi kenaikan biaya operasi penangkapan ikan dan harga kebutuhan pokok dilakukan melalui peningkatan curahan kerja non melaut dalam rumahtangga nelayan. Rumahtangga nelayan responden di daerah Tasikmadu Kecamatan Watulimo pada umumnya memiliki curahan kerja non melaut baik yang dilakukan oleh nelayan maupun istri nelayan. Rata-rata curahan kerja non melaut nelayan sebanyak 86 hari orang kerja (HOK)/tahun, umumnya sebagai penggarap lahan perhutani dan dilakukan pada saat tidak musim ikan. Rata-rata curahan kerja non melaut istri nelayan sebanyak $111 \mathrm{HOK} /$ tahun. Beberapa jenis pekerjaan istri nelayan antara lain sebagai penggarap lahan perhutani, pembuat reyeng (wadah) ikan pindang, penjual bunga, pembuat kripik pisang, guru TK dan membuka toko kelontong.

Pada rumahtangga nelayan responden di Desa Jatirejo Kecamatan Lekok sebagian besar menghabiskan waktu kerja di laut baik sebagai pemilik (juragan) maupun sebagai buruh melaut. Hanya $10 \%$ atau empat orang dari total responden bekerja di luar melaut pada saat musim paceklik sebagai guru ngaji, tukang becak, dan bantu istri buka warung. Rata-rata curahan kerja non melaut empat responden tersebut sebanyak 108 HOK/tahun. Istri nelayan responden di Desa Jatirejo Kecamatan Lekok yang bekerja sebanyak $47,5 \%$ dari total responden. Ratarata waktu kerja yang dicurahkan istri nelayan sebanyak 266 HOK/tahun. Beberapa jenis pekerjaan istri nelayan antara lain sebagai pedagang ikan, buruh pabrik/agen perikanan, warung nasi, toko kelontong dan guru madrasah.

Rumahtangga nelayan dalam menghadapi kenaikan harga BBM bersamaan 
dengan kenaikan harga bahan pokok pangan dapat melakukan strategi meningkatkan curahan kerja non fishing. Oleh karena itu dilakukan simulasi gabungan kenaikan biaya operasional penangkapan ikan 30\%, kenaikan harga bahan pokok $30 \%$ dalam rumahtangga nelayan tetapi diimbangi dengan curahan kerja non fishing suami maupun istri masing-masing 15\%. Tabel 4 disajikan hasil simulasi rumahtangga nelayan meningkatkan curahan kerja non perikanan $15 \%$ yang dilakukan oleh suami maupun istri.
Hasil dari simulasi gabungan dengan meningkatkan curahan kerja non perikanan adalah masih terjadi penurunan dalam total Income rumahtangga $(-27,3 \%)$, serta surplus rumahtangga turun $(-42,23 \%)$. Namun jika dibandingkan dengan hasil yang dapat dilihat pada Tabel 4. Penurunan ini nilainya lebih kecil. Tingkat ketahanan pangan rumahtangga nelayan juga masih mengalami penurunan. Nilai Indeks AKE $(-4,88 \%)$, Indeks AKP $(-12,4)$ dan Indeks ketahanan pangan (21,9\%). Kondisi ketahanan pangan rumahtangga

\section{Tabel 4. Hasil Simulasi Ganda Kenaikan Biaya Melaut $30 \%$ dan Harga Kebutuhan Pokok $30 \%$}

Table 4. Result of the Simulation of Simultant Increase in Aquatic Costs and Basic Needs by $30 \%$

\begin{tabular}{|c|c|c|c|}
\hline Peubah/Variabels & $\begin{array}{l}\text { Sim. Dasarl } \\
\text { Sim. Basic }\end{array}$ & $\begin{array}{c}\text { Skenario Simulasi/ } \\
\text { Scenario } \\
\text { Simulation }\end{array}$ & $\%$ \\
\hline QMP/ Fishing producton in peak season & $3.446,00$ & 2,771 & $-19,5$ \\
\hline QMS/ Fishing production in medium season & $2.440,00$ & 1,632 & $-33,1$ \\
\hline THOKP/ Fishing allocation in peak season & 132,90 & 108 & $-18,7$ \\
\hline THOKS/ Fishing allocation in medium season & 143,11 & 118 & $-17,3$ \\
\hline THOK/Total fishing time allocation & 276,01 & 226 & $-18,0$ \\
\hline RMP/Peak season revenue & $13.784 .722,00$ & $11,084,455$ & $-19,5$ \\
\hline RMS/Medium season revenue & $11.389 .504,00$ & $7,612,799$ & $-33,1$ \\
\hline RF/ Total Fishing revenue & $25.174 .226,00$ & $18,697,255$ & $-25,7$ \\
\hline TBOMP/ Fishing operational cost in peak season & $3.473 .562,00$ & $4,485,312$ & 29,12 \\
\hline TBOMS/Fishing operational cost inmedium season & $5.166 .678,00$ & $6,258,574$ & 21,13 \\
\hline BOF/Total fishing operational cost & $8.640 .240,00$ & $10,743,886$ & 24,34 \\
\hline KFMP/ Fishingprofit in peak season & $10.311 .160,00$ & $6,599,143$ & $-36,0$ \\
\hline KFMS/ Fishingprofit in medium season & $6.222 .826,00$ & $1,354,226$ & $-78,2$ \\
\hline TKF/Total fishing profit & $16.533 .986,00$ & $7,953,368$ & $-51,8$ \\
\hline RRTL/Other Household revenue & $2.343 .194,00$ & $1,918,205$ & $-18,1$ \\
\hline RNF/ Non fishing revenue & $1.200 .152,00$ & 775,162 & $-35,4$ \\
\hline IRT/Total Household Income & $18.877 .180,00$ & $9,871,573$ & $-47,7$ \\
\hline PRT/Total Household Expenditures & $7.538 .209,00$ & $8,438,376$ & 11,94 \\
\hline PPGN/ The major food expenditure & $5.329 .999,00$ & $6,436,445$ & 20,75 \\
\hline PNPGN/ The major non food expenditure & $2.208 .209,00$ & $2,001,932$ & $-9,34$ \\
\hline CBR/Rice consumption & 263,43 & 253 & $-3,92$ \\
\hline $\mathrm{Cl} /$ Fish consumption & 106,03 & 83 & $-21,5$ \\
\hline CSy/Vegetables consumption & 115,23 & 49 & $-57,2$ \\
\hline SRT/Household Surplus & $11.338 .972,00$ & $1,433,196$ & $-87,3$ \\
\hline AKE/Energy Sufficiency Value & $1.637,00$ & 1,526 & $-6,78$ \\
\hline AKP/Protein Sufficiency Value & 53,48 & 44 & $-18,2$ \\
\hline PORPGN/ Food Expenditure Portion & 35,40 & 94 & 165,3 \\
\hline Indeks AKE/AKE Index & 0,82 & 0.7630 & $-6,78$ \\
\hline Indeks AKP/ AKE Index & 1,03 & 0.8408 & $-18,2$ \\
\hline Indeks PORPGN/ Food Expenditure Portion Index & 2,36 & 1.0596 & $-55,0$ \\
\hline Indeks Ketahanan Pangan/ Food Secure Index & 1,40 & 0,8878 & $-36,7$ \\
\hline
\end{tabular}

Sumber : Hasil Simulasi, 2010/Source : Simulation Result, 2010 
nelayan menjadi tahan pangan dengan nilai Indeks Ketahanan Pangan 1,093. Dengan demikian meningkatnya curahan kerja suami dan istri masing-masing sebesar $15 \%$ memberikan hasil yang lebih baik dibandingkan dengan keadaan dimana rumahtangga tidak meningkatkan curahan kerja dalam rumahtangga serta mampu mengembalikan kondisi rumahtangga nelayan pada kondisi yang tahan pangan.

Berdasarkan hasil analisis tabulasi, curahan kerja istri nelayan di Tasikmadu Trenggalek sebesar 111 HOK/tahun, sedangkan istri nelayan di Jatirejo Pasuruan sebesar 266 HOK/tahun. Dengan asumsi dalam satu tahun istri nelayan memiliki 312 HOK, maka ada waktu senggang (leissure) atau produksi rumah tangga (home production time) dari rumahtangga nelayan Tasikmadu Trenggalek sebesar 201 HOK/tahun, sedangkan rumahtangga nelayan Jatirejo Pasuruan sebesar $46 \mathrm{HOK}$ /tahun. Dengan demikian masih ada peluang dari rumahtangga memanfaatkan produksi rumah tangga atau waktu senggang istri nelayan untuk ditingkatkan menjadi waktu pemasaran produksi.

\section{Tabel 5. Hasil Simulasi Ganda Kenaikan Biaya Operasi Melaut dan Harga Kebutuhan Pokok Diimbangi Dengan Kenaikan Curahan Kerja Istri dan Suami}

Table 5. Result of the Simulation of Simultan Increase in Fishing Operation and Price of Basic Needs Balancing with the Increase of Working Allocation Time by Couple

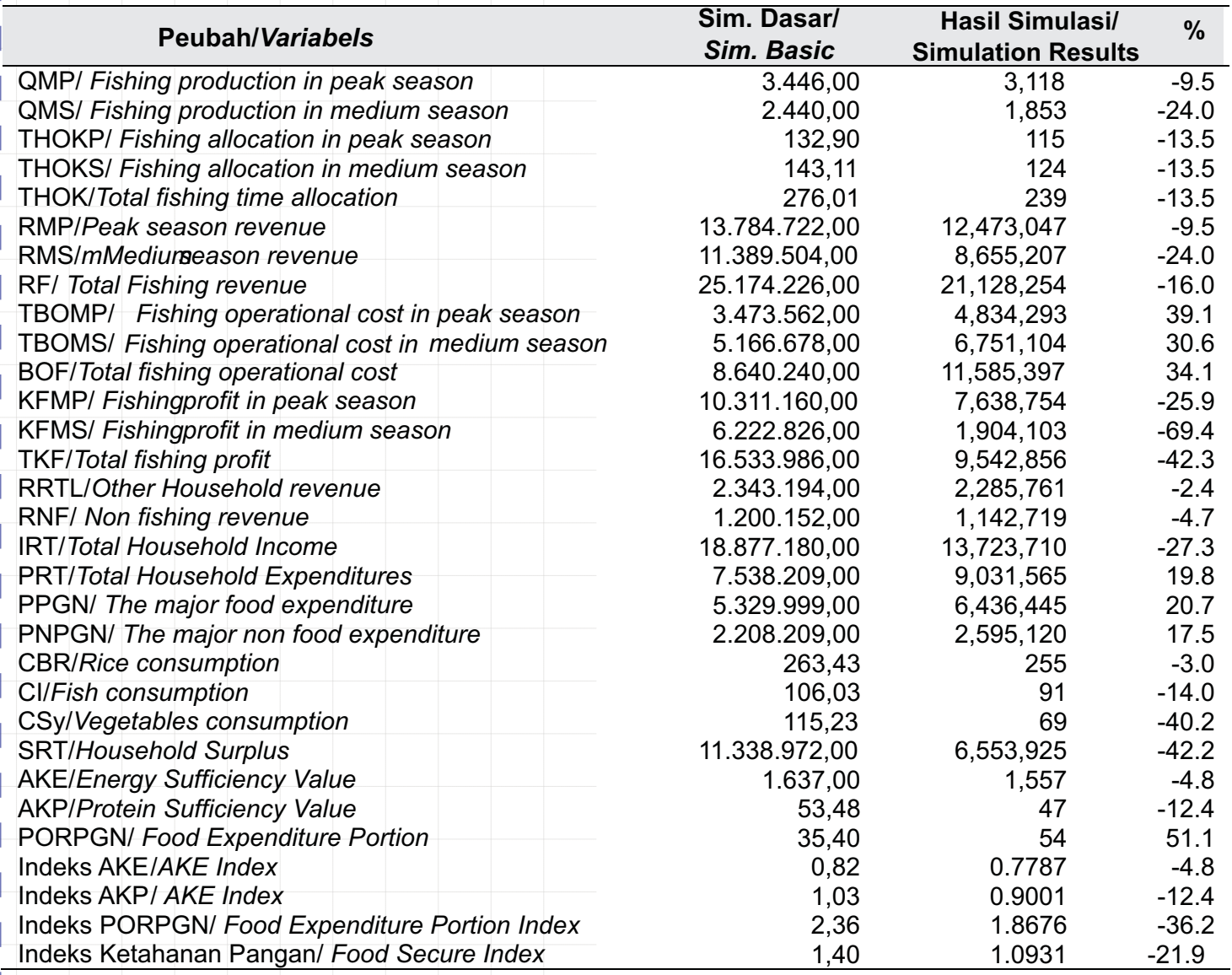

Sumber : Hasil Simulasi, 2010/Source : Simulation Result, 2010 
Kondisi tercukupinya kebutuhan pangan sangat berkaitan dengan perilaku ekonomi rumah tangga, bukan saja perilaku konsumsi pangan sebagai indikator keberhasilan, namun perilaku berproduksi, curahan kerja dan tingkat pendapatan rumahtangga yang saling terkait, sebagai upaya rumahtangga menghadapi ancaman ketahanan pangan. Kegiatan berproduksi, curahan kerja serta pendapatan dalam rumah tangga nelayan skala kecil tidak hanya berasal dari kegiatan melaut, namun juga berasal dari luar kegiatan melaut dan non perikanan. Hal ini merupakan salah satu keputusan rumahtangga dalam strategi coping.

\section{KESIMPULAN DAN IMPLIKASI KEBIJAKAN}

\section{Kesimpulan}

1. Dampak kenaikan harga BBM yang menyebabkan meningkatnya biaya operasi melaut bersama-sama dengan kenaikan harga bahan pokok pangan masing-masing $30 \%$ menyebabkan penurunan pada penerimaan melaut, total pendapatan rumahtangga, kenaikan total pengeluaran rumahtangga dan penurunan surplus rumahtangga. Tingkat ketahanan pangan rumahtangga nelayan juga mengalami penurunan, berdasarkan nilai Indeks AKP, AKE dan Porsi Pengeluaran Pangan. Kondisi rumah tangga nelayan menjadi kurang tahan pangan dengan nilai Indeks Ketahanan Pangan 0,887.

2. Strategi rumahtangga dalam menghadapi kenaikan BBM dan bahan pokok pangan melalui penambahan curahan kerja non perikanan suami dan istri dapat meningkatkan ketahanan pangan rumahtangga nelayan. Kenaikan curahan kerja non perikanan dari suami dan istri masing-masing $15 \%$ mampu mengembalikan kondisi rumahtangga nelayan menjadi tahan pangan.

\section{Implikasi Kebijakan}

1. Hasil tabulasi curahan kerja non perikanan menunjukkan bahwa masih ada peluang dari rumahtangga memanfaatkan produksi rumah tangga serta waktu senggang istri nelayan untuk ditingkatkan menjadi waktu pemasaran produksi. Hal ini mengisyaratkan bahwa masih memungkinkan untuk meningkatkan kesempatan kerja dan kesempatan berusaha istri nelayan pada pasar tenaga kerja. Pengembangan peluang kerja dapat dilakukan melalui usaha produktif pengolahan ikan yang dapat dilakukan istri nelayan guna meningkatkan nilai tambah hasil tangkapan nelayan, terutama ditujukan untuk jenis ikan yang kurang memiliki nilai ekonomis penting dan tidak termasuk dalam komoditas ekspor. Beberapa industri pengolahan ikan yang dapat dikembangkan rumahtangga antara lain pengolahan ikan kering, pembuatan krupuk ikan maupun jenis olahan lainnya yang dapat memberikan nilai tambah untuk meningkatkan pendapatan rumahtangga nelayan. Hal ini merupakan strategi dalam rangka menggerakkan roda perekonomian melalui proses pembangunan ekonomi rumahtangga dan industrialisasi yang berbasis sumberdaya alam menuju kemandirian ekonomi.

2. Dalam rangka menuju kemandirian ekonomi rumahtangga, diperlukan kajian yang lebih mendalam tentang peluang berusaha wanita nelayan di lokasi penelitian untuk pengembangan usaha produktif wanita nelayan menuju industrialisasi pedesaan berbasis sumberdaya lokal.

\section{DAFTAR PUSTAKA}

Annonimous.1993. Evaluasi pembangunan Sub sektor Perikanan Dalam pembangunan Jangka Panjang Tahap I (PJPTI). Jakarta. 
Aryani, F. 1994. Analisis Curahah Kerja dan Konstribusi Penerimaan Keluarga Nelayan Dalam Kegiatan Ekonomi di desa Pantai.Thesis PPS-IPB. Bogor, .

Muhammad, S. E., Susilo, A. Qoid dan M. Primyastanto, 1991. Analisis Pengembangan Usaha Perikanan Skala kecil di selat Madura. Fakultas Perikanan Universitas Brawijaya. Malang.

Muhammad, S. 2002. Kajian Ekonomi Rumah Tangga Nelayan di Jawa Timur: Analisis Simulasi Kebijakan, Pemanfaatan Sumberdaya Perikanan. Disertasi PPS IPB. Bogor.

Purwanti, P. 1994. Curahan Waktu dan Produktivitas Kerja Nelayan di Kabupaten Pasuruan. Thesis FPS UGM. Yogyakarta.

Purwono. G.S. 1991. Alokasi Waktu dan Produktivitas Nelayan di Kecamatan Puger Kabupaten Jember. Thesis FPS UGM. Yogyakarta.

Qoid, A., S. Muhammad, dan M. Musa. 2004. Studi Ekonomi Rumah Tangga Nelayan Pada Perikanan Padat Tangkap di Selat Bali-Muncar. Fakultas Perikanan Universitas Brawijaya. Malang.
Reniati. 1998. Faktor-Faktor yang Mempengaruhi dan Keterkaitan Keputusan Kerja Produksi dan Pengeluaran Rumahtangga Nelayan, Thesis PPS. IPB. Bogor

Singh, I., L. Squire and Strauss. 1986. Agricultural Household Models, Extension, Apllication and Policy. The Johns Hopkins Univ. Press. Baltimore. London.

Sutoyo. 2005. Kajian Ekonomi Rumah Tangga Nelayan Kecil Pada Program Pemberdayaan Pengelolaan Sumberdaya Berbasis Komunitas (PSBK) (Kasus di Muncar Banyuwangi). Thesis PPS Unibraw. Malang.

Tumulyadi, A. 2005. Analisa Ekonomi Rumah Tangga Nelayan Rumpon (Kasus Penangkapan Ikan Cakalang dan Tuna dengan alat Bantu Rumpon di PPI Pondokdadap - Kabupaten Malang. Thesis PPS Unibraw. Malang.

Walpole, R.E. 1995. Pengantar Statistika Edisi ke-3. PT. Gramedia Pustaka Utama. Jakarta 
Lampiran 1. Hasil Estimasi Model Persamaan Simultan

Appendix 1. Results of the Estimated Simultan Equation Model Regression Model

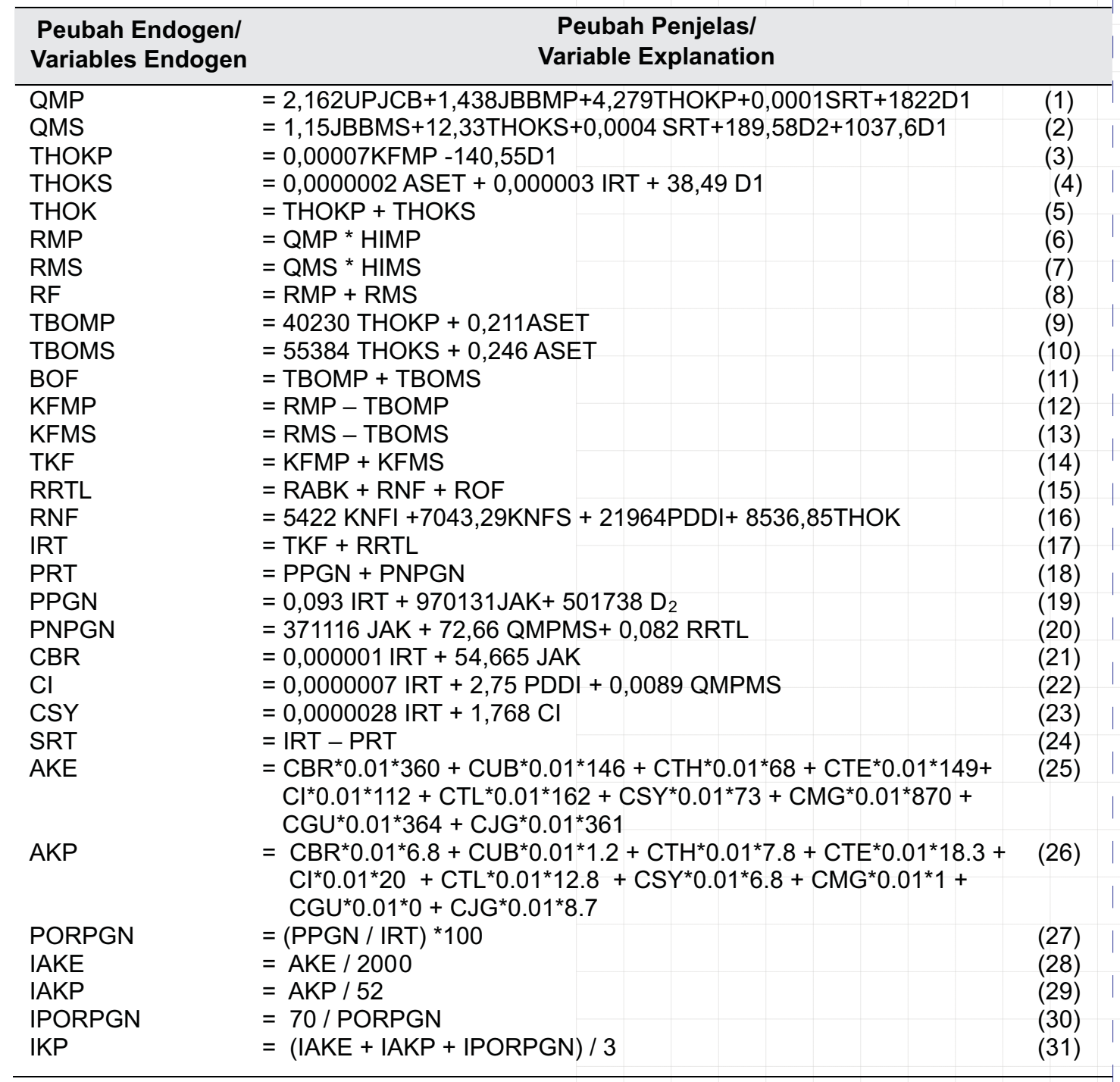

